\title{
Political Rivalry and Social Studies Students Participation in Electioneering Process in Nigeria
}

\author{
Edinyang Sunday David, Ele Blessing Godwin, Ogbaji Dominic Ipuole
}

\begin{abstract}
This paper examined Political Rivalry and Social Studies Students' Participation in Electioneering Processes in Nigeria. The purposes of the research include: To find out how Social Studies students' participation in electioneering process encourages rivalries among political parties in Nigeria and its effect on the security of life and property, to examine the effects of rivalries among political parties orchestrated by Social Studies students' participation in electioneering process and the challenges of policy sustainability in Nigeria. The ex-post facto research method and qualitative research tools were used to generate data for the study. The study was analysed using Structural, functional theory. The following were findings of the study: There is unhealthy rivalry and competition among political parties in Nigeria and such has given room to a lot of monsters such as insecurities of lives and properties, policy unsustainability, projects abandonment; it was also observed that ethnic and religious politics which began during the colonial period is still a common feature of most political parties and politicians in the country. The study recommends that an independent unit should be set up to monitor the execution of government projects to its completion notwithstanding the government that takes overpower, this will go a long way to checkmate wastage of fund on projects which are often left uncompleted. It concludes with the assertion that only an independent electoral commission-free from governmental interference is desirable for the country and we also need to change our values towards selflessness, sincerity, and integrity to improve the gains of our nascent democracy.
\end{abstract}

Index Terms- Political Rivalry, Electioneering Process, Rivalry, Political Party, Social Studies Students' participation.

\section{INTRODUCTION}

The word politics is seen in Nigeria by several persons as a dirty game that should be shunned, due to inequitable propensities, violence, dishonesty, and suspicions that make up the political structure. Nigeria is plural and varied society with various ethnic groups and racial legacy. The continuous increase in the country's population further brings to bear an undue pressure on the activities and cost of governance in the country. The country has witnessed a plethora of instability and changes in its act of governance. There were four successful coups which ushered different administration in the country (Muffett, 2010). History has it that the military-ruled the country for virtually 32 years and democratic governance is in its nascent state of

Edinyang Sunday David, Associate Professor in the Department of Social Science Education, Faculty of Education, University of Calabar, Calabar, Cross River State, Nigeria.

Ele Blessing Godwin, Department of Social Science Education, Faculty of Education, University of Calabar, Cross River State, Nigeria

Ogbaji Dominic Ipuole, Lecturer in the Department of Social Science Education, Faculty of Education, University of Calabar, Calabar, Cross River State transformation. Party system is a phenomenon that is common in a democratic society.

Political rivalry or conflict is a pure contest or competition. According to Acemoglu (2006, 2009), political conflict is a micro-party political battle for the control of the political as well as the economic system, aimed at holding politicians in office continuously. The impacts of this rivalry are mainly linked to infringing the sense of equilibrium between political authority and economic prospects, thereby adversely affecting the relationship between political organisations and economic consequences. Similarly, proposed by Acemoglu and Robinson (2001) and by Dixit and Londregan (1995), the contest of political authority that induces monetary costs because of its retarding effects on growth. Instead of economic efficiency and issues, political competition would create contradictions between economic and political forces and the goals pursued by the elites to control the option of social and economic policy. The success or failure of implemented economic programs then depends on how established regimes handle the political competition.

Electioneering process is a recognised manner in which a person is voted into a political office. The political history of Nigeria has recorded a high level of indifference and political rivalry in its preceding elections. Voters' lack of interest and participation, especially youths' involvement, has been a regular political belief of the country. The high level of rigging recorded in preceding elections, made many Nigerians characterise the electioneering process as "selection" instead of "election."

An electoral system can be seen as a procedure or technique whereby persons of a particular nation select their leaders into diverse political organisations or ranks. It involves procedures, rules, and circumstances for the selection of aspirants for elective positions in an election. The position and involvement of the youths in the electioneering process cannot be challenged or overstressed. For democracy to be useful, expressive, and steady the youths (Social Studies students) should be involved in the modelling process. Adults only cannot take decisions on issues of war and peace because youths also have rights and responsibilities to influence the future they will take over and the kind of life they will be subjected to. The main concern of the economy or the health of the youths and their voices as voters are equally vital in the political entity (Bello, 2019).

However, there is doubt if the relationship between political parties, from the first republic to the present period is healthy. Ideologically, political parties ought to be formed on the bases of ideologies. Whether political parties are designed based on tribal and regional sentiment is needed for further 
investigation. It should be noted that any political party that is formed on ethnic sentiment cannot achieve the goal of national transformation, because Nigeria is a country with many ethnic groups. Thus, the last General Election in 2019 revealed that ethnic and religious interest had affected the party's affiliation in the country, thought states like Gombe and Lagos came out with a surprising result (Tamuno, 2019). The above assertion by Tamuno is ambiguous. Why this is so is because having a substantial amount of votes from another part of the country other than the ethnic group where such a presidential candidate hailed from does not amount to a high level of political culture. Many factors must have played out for somebody to record some level of success in the election, even in an environment outside one ethnicity. To say that political parties in Nigeria are formed only to have access to power, and not the collective interest of the people is not an understatement.

Most of the origin of political parties right from the colonial period were built out from ethnic and regional sentiment, and this has continued to be a severe danger to the growth of democracy in our country (Cinjel, 2015). The style and approach of these parties toward each other is confrontational and not the type that would promote and encourage meaningful development in the country. It is appertaining to this fact that most government in power does not bring opposition closer or seem to take advice from the opposition (Panden, 2006).

There is a wise saying that; if two elephant fights, it is the grass that suffers. The previous is coterminous with the confrontation of political parties in Nigeria and its adverse effects of their activities on the lives of the citizenry. A typical instance can be cited with the issue of insecurity, policy unsustainability, emptying of treasury and government reserve, plethora cases of assassination, cross carpeting or unjust swift from one party to the other in the name of looking for victory instead of representing and standing for a course like ideology and many others. The ugliest part is that most of the electorates in the country follow political parties based on winning and not a particular course of direction (Idang, 2012; Ojo, 2014).

Many studies have been conducted on political parties in Nigeria, but not much is known on the problem that emanated from rivalry among these parties in the country. The beginning of the various problems affecting the growth of democracy and challenges of political rivalry in the country has not been correlated, therefore the need to embark on this research.

\section{PROBLEM STATEMENT}

Electioneering process in Nigeria is characterised by rivalry, deception, violence, thuggery, rigging, tribalism, ethnicity, and many other vices. The involvement of Social Studies students (youths) in the electioneering process highly enhances political rivalry as the politicians used the students to commit many election vices. Nigerian politics have been described by violence, thuggery, greed, love for power, assassination, and rigging in the election right from the First Republic. Transition programs and political activities in Nigeria have been associated with uncertainties, instability, and violence.

\section{RESEARCH QUESTIONS}

The following research questions were devised for the study based on the above problem:

(a) To what extent is Social Studies students' participation in the electioneering process related to political rivalry and the state of insecurity in Nigeria?

(b) How does Social Studies students' participation in the electioneering process leads to rivalry among political parties and affect the state of policy sustainability in Nigeria?

\section{OBJECTIVE OF THE STUDY}

The following are the objectives of the study:

(a) To find out how Social Studies students' participation in the electioneering process encourages rivalries among political parties in Nigeria and how it affects the security of lives and property.

(b) To examine the effects of rivalries among political parties orchestrated by Social Studies students' participation in the electioneering process and the challenges of policy sustainability in Nigeria.

\section{POLITICAL PARTICIPATION IN NIGERIA}

participation is individual involvement in the electoral system. Eakin in Adelekan (2010) described political participation as a process in which individuals participate in their society's political system and can make decisions about what the society's collective objectives are, and how to achieve them. Anifowose (2009) defined political involvement as an activity in which one may voluntarily participate, directly or indirectly. It's an element of political conduct that underlines how people engage in politics. The selection or election of political representatives will elect people into the political system.

Arowolo and Aluko (2010) noted the need for political involvement in the society is to strive for power and acquire it, whether in a civilised or primitive society. This is an essential requirement of a democratic government and also a way of promoting the political structure of the nation. Adelekan (2010) further opined that democracy is the involvement of an individual in making decisions that involve one's life. It is necessary for citizens to fully participate in electoral processes and choose their leaders in a democratic system. All forms of democratic government must hold a high degree of competition, transparency, and the right to civic and political liberties (Arowolo and Aluko, 2010).

The degree of citizens' knowledge, and their level of self-confidence in the democratic system, will decide the measure that will involve the people in the political process. Individual political, economic, cultural, religious, and educational qualifications are among factors which regulate political participation. Politics is spurred on by racial and religious forces that have dominated Nigeria's electioneering cycle since independence in 1960. Former Senate Deputy President Albert Legogie pointed out that there was a divide between the North and the South as well as among Christians and Muslims due to the development of elections (Anifowose, 2011). Politics in Nigeria is considered a deadly game and is 
done with acrimony, rancour, hatred, and other associated evils (Falade 2007). The implications of this are a dangerous state of emergencies and instability.

Most Nigerians' non-participation in an election and other political events is a product of political treachery and false promises. Since being elected to office, the electorates lose confidence in the political process as a result of unfulfilled commitments by politicians (Falade 2008). In Nigeria, the twin issue of ignorance and certain politicians' calculated trickery brings in political indifference. In conclusion, the political culture of Nigeria does not require true democracy to be enshrined and sustained (Falade, 2007).

\section{THE ELECTIONEERING OR ELECTORAL PROCESS}

The act of registering voters, selecting the political parties to vote for, voting, counting ballots, and announcing the results of the election is called electioneering or election method. It is the cornerstone of democratic societies that need to be reliable, vibrant, and that need to serve as the basis for a healthy democracy. A vibrant civil society actively motivates social and political engagement, contributes more and supports citizens ' rights. This controls the state's power and validates its wealth socially, culturally, economically and morally while establishing an atmosphere of mutual respect; dialogue, harmony and consensus. It is, therefore, a process by which legislative body and policies are determined that candidates and political parties are chosen by-election. This electioneering process is the peaceful transfer of power and the lawful execution of authority that involves active citizen participation. Election decides who exercises authority as specified in the Constitution. According to Ologbenla (2003), an electoral system can be seen as a mechanism for electing representatives to power or how a change of government is determined in and at a given time in a specific nation. The Social Sciences Encyclopedia describes election as the process by which qualified members choose, by voting, representatives of governments or groups. It is not the same as election or vote-casting. The electoral process in Nigeria is contradictory and is marked by widespread violence. This is because the institutions of the Nigerian state are predominantly capitalist, and those that power it. This party of Nigerian political economy leaders lack economic pedestal, so they compete for state power to accumulate personal wealth making politics a do or die affair. Violence, race and thuggery are weapons used to get it to obtain access to power and to maintain it. Such deceitful politicians also manipulate youth programs (Social Studies students) to achieve their goals. Students tremendously see civic participation as an actual way of addressing critical problems in their local communities as well as around the country. All over the world, and especially in Nigeria, young people have often led social and political initiatives as they express their concern about environmental problems, jobs, community services and political inequality through social involvement. Youth engagement draws on the need to preserve unity by embracing opposing viewpoints without resorting to violence. The motivation for involvement in any political process should be the idea of voting for causes rather than individuals.
The critical aim of youth engagement would be to provide a platform where youth from various cultures can learn to communicate and share their feelings in dialogue with local, state, and federal officials as youth are valuable tools for political and civil society.

\section{A. Concept of Electoral Fraud}

Electoral fraud is a deliberate vote manipulation or behaving unlawfully aimed at interfering with the election process. It also constitutes a practical breach of electoral laws. Fraud activities include voting-buying, party agents tossing out registration cards for voters, manipulating voting count either by the favoured aspirants' voting share, suppressing the rival aspirants' voting share, or both. Electoral fraud varies from country to country; there can not be forms that are illegal in one country in another. Plenty of election frauds are forbidden in electoral legislation, but some break general laws such as those prohibiting abuse, harassment or libel (Aloysius, 2003).

Tomwarri (2016) states, concerning the present context:

The picture remains unclear, a decade later. Protests by students in sub-Saharan Francophone countries are still frequent, to say nothing lasting. Whatever the governmental responses (i.e. repression or negotiation), universities are still battlefields for centuries to come. Nevertheless, these mobilisations tend to have less effect on political structures than in the preceding decades, particularly before the era of student body massification and pauperisation.

\section{METHODOLOGY}

The study used a combination of methods. First, the study used qualitative tools such as textbooks, journals, newspapers, magazines, conferences and Seminar papers, and internet materials. A qualitative and historical method that was critical and analytical in providing descriptive and historical details was used. The qualitative and historical method provides a flawless insight into the research by understanding the historical details and account of the past by using it to review the present. Also, an ex-post-facto research design was employed to extract records from the Independent National Election Commission (INEC), National Development Plans (N.D.P.), Central Bank of Nigeria, and a lot of others.

\section{A. Conceptual Clarification}

There is no consensus on the idea of democracy or widely agreed meaning. It was conceptualised differently by scholars, politicians, and statesmen. Heater (2001) sees democracy as a tool to politically organise society. He also suggested five fundamental elements which make up a democratic society. These include respect for human life, justice, the rule of law, people's autonomy and individual rights. The concept of Heater, however, can be criticised for its lack of focus on the role of political parties in the democratic process which also highlights the fundamental content of liberal democracy. Diamond (2008), updated the concept above and noted that democracy involves real, all-encompassing competition between individuals and organised groups. This is generally achieved for government posts, involvement in the democratic process and respect for the people's civil and 
political rights, either directly or indirectly.

\section{Political Party}

Foley (2011) broadly describes a political party as a group of individuals or organisations separated from other groups or organisations by its particular purpose in a democratic setting that seeks control of the government through the election of its candidates and the presentation of its credential programs in competition with other parties through the electoral process. Agbaje (2004) describes a political party as a group of people who support a general political cause and who are also bound in politics and views which are the pursuit, acquisition and maintenance of power for as long as they are in government or office. In the same vein, Wilson (2010) describes a political party as an organisation that seeks to select aspirants to public office by providing them with a tag; a party identity by which the electorates are identified.

It is instructive to consider the political party from the perspective of the democratisation and electioneering process This is because it is only in a democracy that the issue of political parties can crop up where people are opportune to elect their leaders through the platform of political parties that provide the enabling environment for people to seek public office.

\section{Political Party Rivalry}

The rivalry is a condition in which two people or groups participate in a long-lasting violent rivalry. It's the mentality between opposing sides, "against each other." Kilduff, Elfenbein, and Staw (2010) described rivalry as a "subjective competitive relationship" requiring "increased involvement in psychology and perceived stakes." Rivalries may be so daunting in some situations that their primary concern is whether their acts will kill or help their opponents. So political rivalry may simply be described as a two-party competition.

Political party rivalry or simply political rivalry in the word of Stephenson (2013) is an unhealthy activity among political parties and usually manifested in the form of keen competition, contention, enmity, conflict, challenges, jealousy, and antagonism. The above view is also corroborated by Bello (2010), who sees political rivalry as an unwholesome contest among political parties in a society and its basis is to harm, injure and damage the potent and vigour of the opponents. It is a known fact that a political party intends to harm each other; this phenomenon will in no way help the society at large.

\section{THEORETICAL FRAMEWORK OF ANALYSIS}

The research followed the theory of structural-function. In the 1950s the structural-functional theory was promoted. The main contributors to that theory were Herbert Spencer and Robert Merton. The theory is a framework that views society as a multifaceted mechanism whose parts function together to promote cohesion and power. The theory offers an essential framework for the study of the various processes. The theory stressed the presence of all systems to perform certain functions for efficient system efficiency. It ensures you can classify the structure according to those functions. Structural functionalism proponents found that the social structure consists of defined behavioural behaviours that have become typical features of a social system. Theory principles:

i) All structure performs some function;

ii) A social structure can either be concrete or analytic;

iii) There are necessary basic conditions for the emergence of a society;

iv) When a structure is not performing its function, vices often appear; and

v) When a structure is weak, unhealthy activities surfaced.

The structural-functional theory is relevant to the topic of the study, "political rivalry and Social Studies students' participation in electioneering process in Nigeria" because of both emphases on the structure that ought to perform certain functions for the efficient functioning of the system.

The theory applies to the study in the following directions: Political parties and their roles: Political parties in Nigeria are created as the political structures to help in strengthening the growth of democratic governance and to sustain development. In a political environment, what goes on in every system that structural functionalism theory analysed is coterminous with happenings in the political environment of Nigeria.

\section{A. RELEVANCE OF THE THEORY TO POLITICAL PARTIES RIVALRY AND THE GROWTH OF INSECURITY IN NIGERIA}

The structural-functional theory is relevant to the study in the following ways: Rivalries among political parties in Nigeria and how it affects the security of lives and property; the challenges of policy sustainability in the country.

Rivalry among Political Parties and Insecurities in Nigeria

Since the colonial period, the operations of political parties in Nigeria have seen many toxic rivalries and massive rivalry. Elites exploited members of their ethnic group at the beginning of time to perceive it as a sharp rivalry between ethnic affiliations. To the North of the country, the element of religion was added to the ethnic background to win mass participation and support (Bello, 2010). The intensity of the competition worsened when Sir Arthur Richard's Constitution was introduced in 1946, and the strong ground for the growth of regionalism was also hatched and broke open in the country. It was at this period that political parties were formed with regional names and some with religious footings. Competition became severe to the point that the country's nationalists were ushering unhealthy disintegrative statement such as; the creation of Nigeria is the mistake of 1914 - Ahmadu Bello, Nigeria is a mere geographical expression - Obafemi Awolowo, Nigeria is the creation of Britain - Abubakar Tafawa Belewa and a lot of others (Cinjel, 2016). This ethnic Chauvinism among political parties formed during the colonial period contributed to deepening confrontational politics in the country. Obasanjo (1990) further stressed that the formation of regional political parties during the Richard constitution of 1946 accentuated strong bitterness which contributed to mutual suspiciousness and increasing cases of insecurities in the country (Wechen, 2015).

Thus, at the granting of independence to Nigeria in 1960 , there were no many changes as related to already ingrained ethics politics. The situation was already deep inside the 
fabric of the Nigerian polity. Political parties then started to use derogatory messages to portray opponents from other parties, and the majority of the Nigerian masses were miss-educated about the ills of ethnic politics. They were led to believe that it was the war of the Yoruba against the Igbo or Hausa-Fulani and so on. The attachment of the masses to the nation-state and the laid structure of federalism in the country was a term consequence. The rules of the game were continually being breached (Dudley, 2008). It was at the period that political parties built a culture of impunity in Nigerian politics. The leaders of the regional parties personalise them, and they quickly got away with wrongdoing in the office. For example, Azikwe survived the inquiry into the finances of the Eastern Nigerian government under his premiership, and chief Awolowo continued to lead the A.G. even after the Coker commission of inquiry had indicted some wrongdoings.

The unhealthy rivalry which was ingrained and embedded in the Nigerian politics and activities of political parties for long has tainted the images of the country in a very deleterious and negative direction. The political parties at the formative stage of the country from 1960 to 1966 were too unconstructive in their approach. For example, the ruling parties discriminated-against a section of the electorates which did not vote for them in the elections. Economic activities in these areas were depressed due to the lack of government investment. In the East, the minorities got the impact of discrimination in the non-Igbo areas of Calabar, Ogoja, and Rivers. In the North, the Tiv, more than any other groups, had a bad dose of Northern People Congress (C.P.C.) discriminatory policies in resource allocation (Anifowose, 2011). Consequently, development in the North was in patches, and this accentuates resentment, which not infrequently took on a violent character and led to the destruction of lives and properties (Jibo, 2011). Too much effort was spent on revenge politics, and far too little was spent on the integration of the diverse ethnic groups by the parties (Jibo, 2011).

The political parties that were created to kick off the democratic transition in 1999 failed to aggregate interest by identifying issue which has cut across cleavages and would strengthen the unity of the country. From observation, In Ebonyi State, former Governor Sam Egwu was locked in a deadly struggle for personalising hegemony with the then-Senate President, Anyim Pius Anyim, who was also an indigene of the state. The face-off was so bad that threats of violence were so much in the air. Several people were killed in Ebonyi in 2001 due to this ugly political development.

In 2011, there was also another keen contest between Goodluck Jonathan of the People Democratic Party and Mohammadu Buhari of Congress of People Convention (C.P.C.). The contest was so hot to the point that after the declaration of the result, a lot of persons were murdered and hard-earned properties worth billions of naira destroyed.

The confrontation in 2011 was a serious threat to the unity of the country. The federal government was left with no other option than to force the governors of the most affected states to declare curfew to avoid the escalation of the situation. The leaders of all the political parties in the country were caution and were also warned to advise the party's members to avoid such a confrontational approach. They were also told to use the court to seek redress, appeal, and entreaty. The presidential aspirant of Congress of People Convention (C.P.C.), Mohammadu Buhari, in an interview with Federal Radio Nigeria, disassociated himself from the acts and rather saw it as an act of criminality by a societal miscreant who only wanted to taint the image of the party. Apart from the cases of physical confrontation from party members, opposition parties sponsor societal miscreants in the form of militia groups, agitators group, secessionist and terrorist groups to cause an uprising in the country (Stephenson, 2014). A lot of groups surfaced during the regime of Yar' Adua, Good luck Jonathan and the Buhari civilian administration. Boko Haram and its faction groups (Yusufi, Shekau, and AlBarnawi) emerged in 2008 as a religious sect but have a lot of political undertones.

There is no doubt that many militia groups like; Movement for the Emancipation of the Niger Delta and a lot of others were formed chiefly to agitate against some wrongdoings by politicians who control political parties. Again, secessionist groups like indigenous people of Biafra, Movement for the Actualisation of the Sovereign State of Biafra (MOSSOB), Oduduwa Republic, Niger Delta Republic, Middle Belt Forum and a lot of others were also the creation of political groups who uses these groups to bolster their political gains. There is also the existence of politically sponsored militia groups such as Agatu Warriors, Water Lions, Red Egbesu, Niger Delta liberation, Niger Delta Volunteer Force, and a lot of others (Wechen, 2015). These leaders of these political parties use the above militia groups to struggle for the allocation of resources that ought to be used for the collective good of the citizens.

However, it is a truism to note that unhealthy political rivalry in Nigeria has affected Nigeria as a State in a negative direction. A lot of homes are now victims of this act; some have lost their breadwinner, a close associate, and some of their dear ones (Gbuile, 2014). It has set a lot of homes apart and a lot of family disarray. Men and women of worth were wasted without any strong police record to tract their perpetrator down. This act is exacerbated and becomes tense during the political campaign and election period. Thus, Clark (2010) observed that it is quite unfortunate that this thing called democracy which was established to put an end in military administration is not quite different from the draconian military government. What have we not seen in the democracy- death, insecurities, unhealthy party rivalry, and a lot of dirty things? It has not solved the situation rather aid the continuation of the act in a different angle. A lot of innocent persons are the victims of these acts. Suffice to say that the major subsystem (political parties) in a democracy that makes democracy worthwhile is failing in her function.

\section{Political Parties and Policy Sustainability in Nigeria}

In a mature democratic society like the U.S.A., Canada, France, Britain, and a lot of others, the candidature is attached to ideology leaning, and the issue of cross carpeting is rare. This thus helps to control the situations were policies and programs of government are abandon and avoided by succeeding government or political groups (Wechen, 2015). 
On the contrary, political parties in Nigeria from the colonial era were formed without a clear ideological base. Most of the political groups surfaced out of ethnic and regional interest. Ethnicity was common and so glaring during the period of Sir Arthur Richard's Constitution in 1946. Political parties were named after ethnic and regional backgrounds (Bello, 2010). The primal factor which often leads to such acts was the inbuilt orientation developed at that time where political parties do not have a good design and organised system of beliefs and philosophies that establish the basis of economic, social, and political idea of their creation.

Ideological learning continues to be a problem in Nigeria politics. This shows why the case of cross carpeting is rampant among Nigerian politicians, and the country's Constitution is still silent about the act despite its adverse effects on the development of the country (Wechen, 2015). This development will not only create a problem in the party but will rather bring about the problem of political will to perform. Thus, the increase in the issue of the abandonment of policies, programs, projects, and a lot of other ensue.

The new All Progressive Congress democratic government under Mohammadu Buhari 's leadership as the President emerged in 2015 as an opposition party to overthrow the then governing party (People Democratic Party). Through study, much of his predecessor's policies and programs were set aside. The contradictions and practices of Nigeria's sidelining programs and initiatives have long existed as a significant challenge to the development of democracy in Nigeria (Bello, 2019). If a particular government abandons a program or initiative to implement another one, the question of contributing more money to a new project becomes a requirement. The latter is as good as resource loss. The problem of political party rivalry often leads to a waste of money, as government programs are abandoned.

Apart from policies, there are symptoms of projects which were abandoned across the shore of the country. Common examples of this are the Gindri water project, PanyamMamba road, Makurdi-Enugu road, Okene-Benin road, Mupo Bridge, Ajakuta Steel Rolling Mill, Jos Steel Rolling Mill and a lot of others. There are also numbers of such cases across states and local Government areas of the federation. The non-existence of policies and projects monitory boards to inspect and monitor the success of policies and projects in Nigeria as it is in other developed countries like the U.S.A., Britain, Germany, Canada and a lot of others contributed to the increasing cases of the menace (Bello, 2019).

The number of abandoned projects in Nigeria today is not only sumptuous but alarming. This menace has affected the socio-economic development of the country in a negative direction. New administration often comes with their party's interest and considers projects and programs of their predecessor more of a legacy rather than a way of improving people's lives. This does not stop at the numerous contracts and projects which were abandoned by political associates, friends, party executives, and family members of the outgone heads. Most of those people do not possess the technical know-how to carry out the projects (Joseph, 2015).

For the past seventeen (17) years, many government projects have been abandoned all over the country. The founder of
African Diaspora Research and Charis Complex, Professor Kole Omotoso, has lamented this ordeal. The University Don who quoted this from the abandoned project audit commission report set up by President Goodluck Jonathan in 2011 , sees the development as uncalled for and root causes of the challenges of socio-economic development in the country. He sees party rivalry and selfishness as the propellant of the menace in society (Dudley, 2008). The political parties that ought to perform the function of strengthening democracy by focusing on developmental programs have now abandoned such function and have now resulted in rivalry and deceit.

\section{CONCLUSION}

The political party's activities in Nigeria have brought despair to Nigerian democracy. They have instigated both intra and ethnic violence and have thus played a centripetal role in retarding growth in the country. Findings revealed that there are unhealthy rivalries and competition among political parties in Nigeria, and this has given room to a lot of monsters such as policy unsustainability, project abandonment, insecurities of lives, and properties. The study also observed that ethnic and religious politics which began during the colonial period is still a common feature of most political parties and politicians in the country; hence politicians and political parties still associate themselves with ethnic and religious institutions.

However, this study found that political rulers made promises that were never fulfilled after winning political power and that Nigerians lost faith and trust in them. Many of the elected leaders consider themselves greedy and not open to the citizens ' needs. Consequently, this leads to the non-entering of democratic and responsible governance into the Nigerian political system.

\section{RECOMMENDATIONS}

The following recommendations were made based on the above findings;

i)An independent unit should be set up to monitor the execution of government projects to its completion notwithstanding the government that takes over power; this will go a long way to checkmate wastage of fund on projects which are often left uncompleted;

ii) Political education in Nigeria should be given immediate consideration and not limited to the school system alone. Citizens, especially the youth, should be properly directed by formal and informal methods on the need for active involvement in the political process that is devoid of ethnic and religious sentiments.

iii) Ultimately, the Independent National Electoral Commission ( INEC) will develop procedures for ensuring that the majority of the electorate participates in the forthcoming general elections in Nigeria. In any step of the electioneering process, the body should be equal and open. The election process should be without emotion, favouritism, bribery, abuse and intimidation. Someone who violates the democratic process and policies will be brought to the account immediately. It will help create equilibrium and confidence in the democratic process and thus increase political participation and possibly eliminate political rivalry. 


\section{REFERENCES}

[1] Acemoglu, D. (2006). A simple model of inefficient institutions. Scandinavian Journal of Economics 108(4): 515-546.

[2] Acemoglu, D. (2009). Introduction to Modern Economic Growth. Princeton and Oxford: Princeton University Press.

[3] Acemoglu, D., and Robinson, J. A. (2001). Inefficient Redistribution. The American Political Science Review 95(3): 649-661.

[4] Adelekan, A.T. (2010) Effects of Role-Play and Moral Dilemma Techniques on Secondary School Students' Achievement in and Attitude to Political Education. An Unpublished PhD Thesis, Faculty of Education, University of Ibadan, Ibadan, Nigeria.

[5] Agbaje, L.(2004). Introduction to political studies. Lagos: Longman

[6] Aloysius, M.O. (2003). Electoral Fraud and the Future of Election in Nigeria 1999-2003 in Godwin, Onu and Abubakar Momoh (Eds) Election and Democratic Consolidation in Nigeria, Lagos Triad Associates.

[7] Anifowose, M. (2009). Political culture and behaviour in Nigeria. Lagos: Malhouse

[8] Anifowose, R. (2011). Violence and politics in Nigeria: The Tiv and Yoruba Experience. Enugu: Nok Publishers Ltd.

[9] Arowolo, D. and Aluko, F.S. (2010) Women and Political Participation in Nigeria. European Journal of Social Sciences 14 (4), 581-593. Basin, A.B.U Journal of Public Administration, 5(2)

[10] Bello, M. (2010). The dawn of a democratic setting in Nigeria and the Challenges. Jos: Decan

[11] Bello, T. T. (2019)." The Role of the Youth in the Electoral Process in Nigeria Politics: From Historical Appraisal." IOSR Journal of Humanities and Social Science (IOSR-JHSS). 24(1), 18-29.

[12] Cinjel, N.D (2015). Boko Haram and the challenges of Population Displacement in the Chad Basin, A.B.U Journal of Public Administration, 5(2)

[13] Clark, T. A. (2010). A Right Honourable Gentleman: The Life and Times of Alhaji Sir Abubakar Tafawa Balewa. Zaria: Hudahuda Publishing Co. Ltd.

[14] Diamond, L. (2008). Class, ethnicity, and democracy in Nigeria. London: Macmillan Press.

[15] Dixit, A., and Londregan, J. (1995). Redistributive politics and economic efficiency. The American Political Science Review. 89(4): 856-866.

[16] Dudley, B.J., (2008). Parties and Politics in Northern Nigeria. London: Frank Cass and Co. Ltd.

[17] Falade, D.A. (2007). The Role of Social Studies Education in Inculcating Democratic Ideals in Nigeria Ife Journal of Theory and Research in Education 10 (1) 16-23.

[18] Falade, D.A. (2008) Questions and Answers on Concepts, Methods, Issues, and Problems in Social Studies. Lagos, Novec' Kol.

[19] Foley, K.(2011). The paradox of civil society, Journal of Democracy, 7(4), 122-132

[20] Gbuile, B. (2014). Nigeria's Five Majors. Onitsha: Africana Educational Publishers (Nig) Ltd.

[21] Heater, D. (2001). Political ideas in the modern world. London: Longman

[22] Idang, G. J. (2012). Nigeria: Internal Politics and Foreign Policy. Ibadan: University of Ibadan Press.

[23] Jibo, M. (2011). Chieftaincy and Politics: The Tor Tiv in the Politics and Administration of Tiv land. Frankfurt: Peter Lang.

[24] Joseph, R. (2015). Democracy and Prebendal Politics in Nigeria. Ibadan: Spectrum Books Ltd.

[25] Kilduff, G. J., Elfenbein, H. A., and Staw, B. M. (2010). "The Psychology of Rivalry: A Relationally Dependent Analysis of Competition". Academy of Management Journal. 53 (5): 943-969.

[26] Muffett, D. J. M. (2010). Let Truth Be Told: The Coups d'etat of 1966. Zaria: Hudahuda Publishing Company, 108(4): 515-546.

[27] Obasanjo, O. (1990). Not my Will. Ibadan: University press Ltd.

[28] Ojo, O. M. (2014). Electoral Security and Democratic Consolidation in Nigeria. In Ikuejube, G and Olupayimo, D.Z. (eds) Nigeria's Internal Security Challenges: Strategies for Sustainable Development, Ibadan, John Archers. 1-28.

[29] Ologbenla. D. (2003). Political Instability, Conflict and the 2003 General Election in Remi

[30] Anifowose and Tunde Babawale (eds) 2003 General Elections and Democratic Consolidation in Nigeria Lagos: Friedrich Ebert Stiftung (F.E.S.) 2003: $69-100$.

[31] Panden, J.N. (2006). Ahmadu Bello Sardauna of Sokoto: Values and Leadership in Nigeria. Zaria: Hadahuda Publishing Company Ltd.

[32] Rodrik, D. (1999). Where did all the growth go? External shocks, social conflict, and growth collapse. Journal of Economic Growth 4: 385-412.

[33] Stephenson, H. (2013). Military and democratic governance in Nigeria.Jos: Decan
[34] Stephenson, M. (2014). Comparative studies of governance in third world countries, Journal of Administrative Studies, 3(2), 110-115.

[35] Tamuno, T. (2019). Nigeria and Elective Representation 1923-1949. London: Heinemann.

[36] Tomwarri, E. (2016). Political Participation and Electoral Fraud in Nigeria: A Case Study of the Fourth Republic. Being Seminar Paper at the Department of Political Science and Pu8blic Administration, University of Benin.

[37] Wechen, D. (2015). Comparing Military and democratic governance in Nigeria. Lagos: Longman Group of company

[38] Wilson, O. (2010). Democracy and instability in Nigeria. Longman: Onitsha

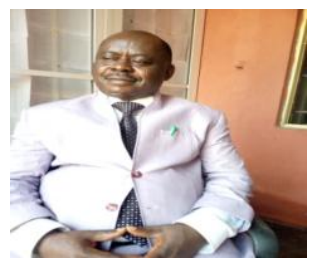

First Author: Edinyang, Sunday David, Is an Associate Professor in the Department of Social Science Education, Faculty of Education, University of Calabar, Calabar, Cross River State, Nigeria. He was a one time coordinator of Environment Education at the University of Calabar, also one time Post Graduate School Representative at the Department of Social Science Education, He is currently the head of Department of The Department of Social Science Education. $\mathrm{He}$ is form Nsit Atai Local Government of Akwa Ibom State, Nigeria. He got his Bachelor in Education Political Science degree from the University of Calabar, he also got his master degree and Ph.D. in Social Studies from the the same University. He is happily married and the marriage is blessed with six children (three boys and three girls). He is a prolific writer who has published several books and article as can be seen on his google scholar profile: https://scholar.google.com/citations?user=9gyvGaMAAAAJ\&hl=en.

Ele, Blessing Godwin Is a Masters Degree Student with the Department of Social Science Education, Faculty of Education, University of Calabar, Cross River State, Nigeria. Ogbaji, Dominic Ipuole is a Lecturer in the Department of Social Science Education, Faculty of Education, University of Calabar, Calabar, Cross River State. He has a Bachelor in Education Social Studies degree and currently pursuing his Masters and Ph.D. in Social Studies from the same department. He has co-authored several article. 